Please do not remove this page

RMIT

UNIVERSITY

\title{
Getting published: group support for academic librarians
}

Sullivan, Doreen; Leong, Julia; Yee, Annie; Giddens, Daniel; Phillips, Robyn

https://researchrepository.rmit.edu.au/esploro/outputs/9921858927401341/filesAndLinks?institution=61 RMIT_INST\&index=null

Sullivan, D., Leong, J., Yee, A., Giddens, D., \& Phillips, R. (2013). Getting published: group support for academic librarians. Library Management, 34(8/9), 690-704. https://doi.org/10.1108/LM-03-2013-0026

Document Version: Accepted Manuscript

Published Version: https://doi.org/10.1108/LM-03-2013-0026

Repository homepage: https://researchrepository.rmit.edu.au

(C) 2013 Emerald Group Publishing Limited

Downloaded On 2023/04/26 10:25:53 +1000

Please do not remove this page 
Thank you for downloading this document from the RMIT Research Repository.

The RMIT Research Repository is an open access database showcasing the research outputs of RMIT University researchers.

RMIT Research Repository: http://researchbank.rmit.edu.au/

\section{Citation:}

Sullivan, D, Leong, J, Yee, A, Giddens, D and Phillips, R 2013, 'Getting published: group support for academic librarians', Library Management, vol. 34, no. 8/9, pp. 690-704.

See this record in the RMIT Research Repository at:

http://researchbank.rmit.edu.au/view/rmit:22484

Version: Accepted Manuscript

Copyright Statement: @ 2013 Emerald Group Publishing Limited

Link to Published Version:

http://dx.doi.org/10.1108/LM-03-2013-0026 


\title{
Getting published: Group support for academic librarians
}

\begin{abstract}
Purpose - This paper offers an effective model for increasing professionals' competence, enthusiasm and success in writing and publishing.

Design/methodology/approach - Recent articles on writing groups in the field of library and information science are reviewed and a case study of a group at RMIT University Library is presented. The authors were the facilitator and group members who were librarians, most with relative inexperience in research, writing, presenting, and getting published. A self-rating confidence survey was created to establish developmental priorities which were then addressed through input from experts, practical application and reflection, and constructive advice and support from group members. Group effectiveness and outcomes were evaluated at mid- and end-point review meetings, through a post-intervention confidence survey and by tracking publication output.
\end{abstract}

Findings - The group became a cohesive, task-focused and productive team. A post-intervention confidence survey evidenced improvements on all survey items at a team level. Each member affirmed that they had gained substantial knowledge of writing, presentation and research techniques and understanding of the publication process. Publication output increased over the benchmark year of 2010, and in 2011 and 2012 exceeded initial targets.

Practical implications - The model presented offers a practical and effective approach to increasing competence and output in writing, presenting, research, and getting published and can be easily adopted by others.

Originality/value - Most literature reviews on library professional writing groups relate to professionals required to publish. The Get Published Group comprised Australian librarians writing voluntarily.

Keywords Writing groups, Academic libraries, Professional development

Paper type Case study

\section{Introduction}

The value of sharing knowledge and effective practice through publication could be seen as self-evident to library and information science professionals. Identifying, acquiring, preserving, and providing access to information have long been our core activities (Raish, 2003, p. 2) and supporting knowledge creation and publishing others' work is increasingly seen as our domain (Lewis, 2010, p. 3). Despite this, many library professionals do not actively present or publish their own research, viewpoints, and evidence-based practice. At RMIT University there were a number of opportunities to participate in training in this area within the University and through the library profession, but take-up by librarians had been low. Senior library staff recognized a need to increase the number of conference presentations and publications by staff and supported the formation of a group to address this issue. It was hoped that an in-house supportive group would attract staff interest and result in a breakthrough to greater activity, as indeed happened.

To this end the Get Published Group was formed comprising librarians who participated voluntarily and who, with one exception, were relatively inexperienced in research, writing, presenting, and getting published. It was facilitated by the staff development librarian and met approximately every two months from mid-2011 to the end of 2012. The authors of this paper were the facilitator and several group members. A participant self-rated confidence survey was created to establish developmental priorities which were then addressed through a range of learning approaches: input from experts from within, and outside of, the group; practical application and reflection; and constructive advice and support from group members. Group effectiveness was conceptualized from Tuckman's stages of group development, which is referenced in both group and team development literature (Bonebright, 2010; DuFrene and Lehman, 
2011; West, 2004), and team principles including those found in Team Management Systems' models. Individual Team Management Profiles (Team Management Systems, 2009) and a related workshop were utilized to set the foundation for good teamwork. To a large extent the terms 'group' and 'team' are used interchangeably in this paper. Notwithstanding this, the 'group' has been seen as quickly becoming a 'team' in the sense that individuals not only completed their tasks, but effectively supported each other and synchronized their efforts (Mohammed and Ferzandi, 2007). Group effectiveness and outcomes were evaluated at mid- and end-point review meetings, through a post-intervention confidence survey and by tracking publication output. The paper reports on positive outcomes and discusses the practical implications or value of adopting this approach. It begins with an overview of recent literature reporting on writing groups in the library and information science field and then provides a case study of the RMIT University Library Get Published Group.

\section{Literature review}

Writing groups are common in academia (Haas, 2012; McGrail et al., 2006) and the creative arts, but are significantly less common for employees of libraries and other information science organizations. Academic writing groups can be traced back over 200 years (Gere, 1987), yet the literature on workplace library writing groups is relatively modest. An examination of how and why academic writing groups work and their benefits has become a focus in recent decades as university publishing requirements of staff has increased.

Writing or writers' groups support members in getting published. Two main types of groups exist. The first has a primary focus on the writing and appraisal of manuscripts; the focus of the second type of group lies with learning, publishing acumen and acculturation, and psychosocial support (McGrail et al., 2006). The RMIT University Get Published Group, described later in this article, falls into the second category. Writing groups tend to cluster in academic libraries because academic libraries or their institutions at least, have a long history of encouraging scholarly communication. Despite this, there is nothing to stop writing groups forming in other sectors. However, with public and special libraries in particular, the demands to meet the service needs of clients or the need for management vetting of material may prove to be insurmountable barriers to a workplace group.

Benefits of implementing writing groups include: increased publication rates (McGrail et al., 2006); accountability; increased confidence as a writer (Morss and Murray, 2001); demystifying the publishing process (Cameron et al., 2009); fostering collegiality, collaboration and networking; and information exchange such as sharing knowledge about intellectual property (Grant and Knowles, 2000). In a systematic review of interventions in academia such as writing courses, support groups, and coaching to increase publication output, writing groups were found to be the most beneficial and effective. These support groups resulted in the most publications, although the other two methods were still valuable (McGrail et al., 2006).

Barriers to publishing include lack of time, lack of institutional support, lack of skills and lack of confidence (Clapton, 2010). Emotional and psychological barriers such as fear, anxiety and self-doubt can be factors (Cameron et al., 2009; Sullivan, 2012b). Increased confidence is often touted as a soft outcome from a writing intervention (Fallon, 2012; Morss and Murray, 2001). However, a study at an Australian regional university found confidence was the most significant factor in achieving higher publication output of peer-reviewed material (Hemmings et al., 2005). Growth in confidence in writing for publication was mentioned in most of the library-related studies and this confidence was often expressed in other areas as well, such as teaching, 
status, or professional identity (Blessinger et al., 2010; Grant et al., 2010; Tysick and Babb, 2006).

Writing groups enhance professional development. In the library sphere, participants contribute to the literature, and often contribute to other disciplines, thereby extending outreach beyond the library. Reading of professional and subject literature is also important. Readers develop and reinforce knowledge of their professions. According to Tenopir et al. (2011, p. 7), who write about academic reading patterns, "[r]eading more is correlated with success--faculty members who report reading more also publish more and are more likely to have won professional awards than their colleagues who report reading less."

The literature on creative, academic and institutional writing groups is substantial (Haas, 2012). Literature on various aspects of writing for publication for the library profession, including practical guidance, is solid (Bradley, 2008; Clapton, 2010; Fallon, 2009, 2012; Gordon, 2004; Leslie, 2010). Yet reports of writers' groups designed to support library staff toward publication in the library and information science (LIS) literature are few. In one respect this is surprising since a writers' group can encompass expert or peer mentoring and surveyed library staff often state that mentoring is one of the most preferred ways to learn about the publishing process and as support to increase writing skills (Bradley, 2008; Clapton, 2010). In her study of library practitioners and publication, Clapton (2010) found that peer encouragement, along with time release, was the most requested support approach. Workplace writing groups require institutional backing regardless of how informal or self-sufficient such groups may be. Those libraries that provide support tend to have the most active publication record.

Many of the library writing groups mentioned in the literature were formed to meet publishing requirements for tenure in North American academic libraries (Blessinger et al., 2010; Campbell et al., 2011; Exner and Houk, 2010; Palmer and Matz, 2006; SaponWhite et al., 2004). On occasion, non-library academic writing groups have included librarians, such as the North West England cross-disciplinary writers' group (Grant et al., 2010). The study is included as a library writing group in this literature review because the authors address why the group is important for the library profession, notably for publishing evidence-based material specifically for LIS. Even within the literature about publishing for library tenure requirements, often a writers' group for librarians is not mentioned in sufficient detail for other library staff to implement their own version. For example, the Georgetown Scholarly Writing Group began as an informal group that met once each month for lunch and discussion, which led to other writing support initiatives such as a sabbatical program, but no extra information about the group itself is offered (Johnsrud, 2011).

Those writing groups formed to increase publication and to help staff members to learn the ropes of the publishing process may need the collective wisdom of a group where there are not enough staff members experienced in the specifics of publishing to individually mentor those undergoing tenure publication requirements. Librarians might have gained tenure in earlier years where the publishing requirements were not as rigorous or dependent on publishing as in recent years (Exner and Houk, 2010).

\section{Groups guided by books}

A number of groups have based their formation and trajectory on books as a guide, perhaps because staff members experienced in publishing were not available or junior staff members are reluctant to approach them. Junior librarians from the University of Buffalo based their group on exercises and methods suggested by Elizabeth Rankin (2001) in her book The Work of Writing (Tysick and Babb, 2006). One of the two writing groups at the University of North Carolina was the Agraphia group, based on "the group 
described by Paul Silvia [2007] in his book How to Write a Lot: A Practical Guide to Productive Academic Writing ... [which] aims to help people in academia become more productive writers" (Exner and Houk, 2010, p. 180). Matheson (2010, p. 34) and her colleagues attended a workshop conducted by Tara Gray, the author of Publish and Flourish: Become a Prolific Scholar (2005). Gray showed how to create a writing group and demonstrated why writers' groups were excellent support mechanisms for authors. This group met weekly and was also a critique group and an accountability group. Members had to commit to writing each day and to also record their writing progress and report back to the group about what was achieved.

\section{Critique or review groups}

The Research and Writing group run for academic librarians at Oregon State University reviewed manuscripts and presentations for members. While many felt the group was worthwhile, out of an array of publishing support, the writing group was the least attended (Sapon-White et al., 2004). It was appreciated more as a venue to discover what colleagues were doing than as a place to receive criticism. The authors suggested that possibly both the fear of harsh criticism and the time needed to review another's work on top of current duties could account for low attendance. The Louisiana State University critique group also found few members were willing to submit material to be reviewed (Blessinger et al., 2010), even though founding members were "braced for an onslaught of submissions" (Blessinger et al., 2010, p. 28). The focus was entirely on the writing and later, presentation. However, even with the initial reluctance to submit work to the writing group, it proved its value to the library. Although the appraisal aspects of some writing groups work well (Mathson, 2010), it is possible that at least initially a low submission rate can be attributed to inexperience (Tysick and Babb, 2006). The University of Buffalo Academic Writing Group decided to meet to discuss other issues even when manuscripts were not available for assessment.

\section{Group accountability and productivity}

Both Mathson (2010) and Exner and Houk (2010) explicitly stated the need for accountability, such as deadlines and mapping progress, as a feature of a successful library writing group. Exner and Houk (2010, p. 181) noted with one of the writing groups highlighted in their article - a 'Pub \& Grub' group that met at lunchtimes to discuss writing issues and to set goals - that if no one met their goals for several consecutive weeks then the sense of momentum and accountability was dissipated.

An offshoot of accountability is often a greater publication output. All the groups that measured their publication output showed an increase. Mathson's group (2010) met weekly and each member also had a commitment to writing fifteen to thirty minutes each day. Four of the group members published articles in the first year of the group's existence and another wrote an introduction for a book she had researched. The academic writing group at the University of Buffalo produced five peer reviewed articles from six group members in its two years, along with a number of non-refereed articles. The group set a goal to have each member publish either a peer-reviewed article or book. The collaborative library writing group at East Tennessee State University reported that they had produced "four articles and nine presentations, with several in-progress and pending efforts" (Campbell et al., 2011, p. 17).

INSERT TABLE HERE

Table I: Library Writing Groups

The value of a writing group 
Even for those countries where writing for publication is voluntary, such as Australia (Bradley, 2008) and Ireland (Fallon, 2009), instead of required for academic promotion, many library staff members are enthusiastic about learning how to get published. While Bradley (2008) has suggested that lack of tenure can act as a barrier to publication, writing independently of tenure requirements also has a freedom where keen participants need not be restricted to a particular type of professional library writing. Tenured or non-tenured, many staff members are keen to write for the profession. Courses and workshops often provide a starting point, but how does one keep up the momentum? How does one align writing for publication with organizational goals? A writing group such as the RMIT University Library Get Published Group may provide the answer. The remainder of this paper presents a case study on the group and offers an effective model which can be adopted or adapted.

\section{The RMIT University Library Get Published Group}

\section{Formation of the group}

As outlined in the Introduction, senior library staff at RMIT University Library wished to foster an increased number of conference presentations and publications by library staff. There was also a desire to see a greater emphasis on evidence-based practice in the library. A number of enthusiastic new professionals were beginning to give conference papers; however they were inexperienced in this and in writing papers. These factors, together with the willingness and availability of two staff members with adequate experience to act as peer mentors, led to the formation of a voluntary developmental group organized by the staff development librarian. The call for participation gave two stated aims:

1. to develop University Library staff output of conference papers and presentations, journal articles and book chapters; and

2. to provide a supportive and stimulating environment which promotes confidence and quality of materials produced.

Eight librarians expressed interest in joining the group. One soon withdrew having decided its direction did not match her need and one left part-way through the life of the group to concentrate on a new role. Occasionally additional staff attended meetings on topics of special interest; however the membership of the core group was stable. At the initial meeting members shared their current level of experience in the areas of writing, researching, presenting, and publishing. To ensure time was well used, terms of reference were agreed. A document was developed that included aims, performance indicators, reporting obligations, time commitment, and frequency of meetings. These actions align with Tuckman's understanding of the 'forming' stage of group development (West, 2004, p. 29) and served to set up accountability expectations. A positive impact of accountability on publication output was evidenced in Mathson's group (2010) and the University of Buffalo group (Campbell et al., 2011, p. 17). The performance indicator set for the Get Published Group output was that $75 \%$ of group members would publish or present at a conference in both 2011/12 and 2012/13. Meetings were held five times per year and were scheduled to accommodate the demands of the academic year. Time commitment was two hours per meeting plus preparation, such as organizing a meeting or writing minutes. Additionally much of the writing for publication or preparing a presentation would be done outside of work time.

Topics suggested by members and the staff development librarian were discussed and prioritized. A confidence survey was devised as a way to self-assess and gauge 
levels of confidence and competence in a variety of topic areas. To do this the initial topic list was supplemented from course contents available on the web at the time which were similar to those given by Fallon (2010). Findings helped to set priorities and plan a program. To help to quickly form a harmonious, efficient, and productive group, the group utilized a team profiling instrument, the Team Management Profile, and participated in a workshop with an in-house facilitator. Completing the survey took approximately fifteen minutes and this was done online. Each participant received a detailed report which included work preferences and tips for working with others who had differing work preferences. There were options to share with each individual team member to enhance working relationships, and to use an online application which provided suggested strategies for working harmoniously with a particular individual. For example, an individual's approach to deadlines and preferences for processing of information could be accommodated and necessary adjustments made to reduce conflict.

\section{Group meetings}

The most common agenda of group meetings was:

- sharing current individual actions or successes, such as submission of conference abstracts or a new publication (30 minutes),

- receiving input on topics related to writing, publishing and presenting from peers or experts ( 80 minutes), and

- checking future meeting arrangements (10 minutes).

Writing and critique of others' work mostly occurred in non-meeting times, although not exclusively so. Rather than following a comprehensive curriculum, learning topics were chosen to build on existing knowledge and to fill gaps. Below is the list of topics covered in chronological order.

- Finding conference, journal article and book chapter calls (peer presenters)

- Research methodologies (invited academics)

- Copyright and intellectual property for authors (University Copyright expert) and peer review processes (peer presenter)

- Presentation techniques (guest librarian)

- Writing skills and peer critique exercise (learning advisor)

- The editor's perspective (guest journal editor)

- Mini presentation practice (action learning)

- RMIT University Human Research Ethics Committee requirements (committee officer)

- Developing research proposals/identifying research topics (University expert).

Finding appropriate conferences and calls for journal articles and book chapters were selected as the first topics. Held as a workshop, this meeting was facilitated by two experienced group members. This resulted in a more targeted approach to selecting suitable conferences or publications to which to submit. The content on finding calls for publication was later expanded and published as an article (Sullivan, 2012a). The group was fortunate to receive input from experts within the university and outside of it. A challenging, yet enjoyable workshop on writing skills involved group members in preparing a sample submission for Incite, the Australian Library and Information Association news magazine, on one of the advertised forthcoming issue themes. For this 
exercise, a university study and learning advisor facilitated the group's constructive critique of others' writing. Subsequently, group members were encouraged to submit their articles for publication and two were accepted (Giddens, 2012; Sullivan, 2012c). Another excellent session was given by an external speaker on presentation skills. Following this, group members were inspired to each do a brief practice presentation at a future meeting, using a three minute time limit and one PowerPoint slide. This idea was based on a popular competition, the Three Minute Thesis (University of Queensland, 2012), which is run at many universities for higher degree students who seek to present their research in an engaging and accessible manner. A second contributor from outside of the university was the editor of the Australian Library Journal. This session covered the journal's requirements for publication and gave insight into the editor's viewpoint. It familiarized participants with the type of literature included in the journal and showed how to maximise the likelihood of having an article accepted.

Recognising a need for more understanding of the research process, four academics from the RMIT University Information Management Program were invited to speak to the group about the application of a variety of research methodologies in their own research and publications. This informal session demystified the research process to an extent and built participants' self-confidence in their own abilities. At a later meeting the Ethics Officer from RMIT University's Human Research Ethics Committee came to present on human research ethics procedures and practices and this information was new to many. Another session covered copyright in relation to author rights, including checking publisher agreement details in regard to both adding an item to an institutional repository and to reproducing your work.

The final meeting covered how to develop suitable topics for writing and research. This was led by an experienced adviser to higher degree students who was interested that librarians were motivated regarding research and publication when they were not required to engage in these. This was an informal and fascinating session. Participants were asked to consider "what the problem was" and examples of work-based challenges were then worked through to identify research questions and to consider the research methodologies which could be used to address these questions. A surprisingly large number of possible research topics came out of this exercise.

\section{Activity outside of group meetings}

In addition to interaction in regular meetings, significant support was offered for individuals for their conference presentations and writing. Team members were generous in offering constructive criticism and suggesting edits to pieces of writing. The team developed high levels of trust and this enabled each member to develop their skills at their own pace without any sense of pressure or embarrassment.

At least half of the members attended one of several related external training sessions either before or during the period of the operation of the group. Most of these were one to two day workshops arranged by library consortia or offered in association with a conference. Knowledge gained from these occasions enabled members to contribute ideas and enrich others' learning journeys.

\section{Outcomes}

When Bradley (2008) surveyed conference authors from the Australian 2006 New Librarians' Symposium, she found that, while there is often strong intrinsic motivation to write, potential authors can lack time and know-how. The Get Published Group, by having some institutional support, and by arranging peers or experts to share their knowledge, somewhat overcame these barriers, particularly the barriers to learning how to conduct scholarly writing. Productivity increased, as did confidence of members of the 
writing group. Anecdotal evidence suggests that some individuals' confidence increased, not only in the area of the publishing process, but across the board. In detailing a university writing group Grant et al. (2010, p. 51) suggested "[f]rom an organizational perspective, increased levels of confidence in staff can only beneficially enhance its operations".

\section{Group effectiveness}

Team goals focused on both output and "providing a supportive and stimulating environment which promotes confidence and quality of material produced". A mid-point review against the Terms of Reference, and end-point review discussions affirmed that cohesive, task-focused and productive teamwork was in place. The knowledge of team members and their strengths which was gained in early meetings allowed use of peer skills and abilities when appropriate, while being aware of when expert assistance from outside of the group was needed (Franz, 2012, p. 46). Starting a writing group is possible without experts in the group. However it certainly helped in the Get Published Group to have two experienced writers to guide group members. Their knowledge of the publishing world was a driving force and their professional contacts provided leaders for mini workshops and talks. The team member profiling and workshop was useful to examine member preferences, and how to organize activities well. Participants tend early on to be focused on their individual learning needs, and perhaps their own sense of inadequacy; therefore actions to bring integrated team behaviour were taken deliberately. Early work to agree on a group's focus (Campbell et al., 2011, p. 16), identify learning needs and prioritize content, schedule activities, and allocate responsibilities pays off. The quick progression through the stages of group 'forming' and 'norming' to 'performing' with minimal evidence of 'storming' highlighted there was effective functioning as a team. Participants spoke enthusiastically of abiding by the Terms of Reference, exceeding output targets, high trust levels, collegiality, and a safe supportive group environment. Less experienced participants did not shy away from sharing fears and lack of confidence in certain aspects. The safe and supportive environment was viewed by group members as a significant factor in growth of confidence, an important factor for achieving higher output (Cameron et al., 2009; Sullivan, 2012b).

\section{Confidence survey}

Confidence was interpreted by the group to be a significant indicator of the knowledge, competence and practical skills of group members in publishing, presenting and group processes. At the outset, confidence levels were measured to provide a benchmark and the results helped with the planning and scheduling of meeting topics. A survey comprised of 27 questions asked participants to rate, on a 10-point scale, how confident they felt on various topics related to presenting and publishing. The topics were based on the expert opinions of the staff development librarian, taking into consideration the interests of group members. Unlike the Likert Scale with a neutral point, a ten-point scale to force a decision was used for simple comparison and calculation across the pre- and post-surveys. It was originally designed as an internal tool to be used within the group. The data was collected and collated in Survey Monkey software. No individuals were identified. There were eight respondents to the initial May 2011 survey and seven of the original eight for the post-survey in October 2012. Results demonstrated that, at a group level, confidence increased for all survey items. The greatest increases were in the areas listed in the table below:

INSERT TABLE HERE 
Table 2: Confidence Survey: Topics surveyed in March 2011 and October 2012 with greater than $30 \%$ increase in confidence.

The increase for the remaining items ranged from 4.9-29\%. Of wider interest may be the items for which group members had the lowest confidence at the outset of the group. These were:

- Copyright for authors (4.63 out of 10 where 10 is high confidence);

- Use of research methodologies, e.g. survey techniques, case study, phenomenology (4.63).

- Peer review process (5.13).

Through developing and participating in sessions, members have been able to build more knowledge of the writing and publication process for several publication types including book reviews, newsletters, journal articles and conference papers. Members have gained more in-depth insight into how to select and target appropriate outlets and have benefited from understanding issues pertaining to academic publications such as the importance of peer review, research ethics and copyright. For about half the group members, who work in roles where they liaise directly with academic staff, there have been additional and unanticipated benefits. The impact of knowledge gained has enabled more effective communication with research staff in the university, resulting in proposals for future joint papers. This level of collaboration was new for the librarians involved. Librarians are perhaps too often considered support staff to scholarship and not necessarily appreciated as writers and scholars in their own right (Fallon, 2009; Gannon-Leary and Bent, 2010). The writing group helped the individuals concerned to raise their profiles and helped to address this concern. As well as being invited to work on joint papers, they have been able to more effectively promote and encourage deposit of material in the RMIT University Research Repository.

\section{Publication output}

Publication output of participants surpassed the target set which was "at least $75 \%$ of group members have a library, information science or work-related book review, news piece, article, paper, book chapter, or book published (online, print, etc.) or present a conference paper, individually or jointly, in both 2011/2012 and 2012/2013". One member of the group had her first peer-reviewed article published and three individually presented their first peer-reviewed conference paper.

The most dramatic increase in output was in book reviewing which has the sidebenefit of exposing the reviewer to ideas with which they might not otherwise engage. In addition to letting others in the industry know at a glance what a book (or other media) is about and whether it might be worth consulting or purchasing, concentrated reading plus concise writing for the review reinforces knowledge of current LIS practices and trends. Keeping abreast of trends - also often evidenced in calls for papers - is a valuable contribution to a writers' group. The number and quality of reviews was much appreciated by the editors to whom they were submitted. Feedback from the editor of reviews for The Australian Library Journal mentioned the value of reviews which provide an Australasian perspective (G.E. Gorman 2012, pers. comm., 25 October). He noted they are read, appreciated internationally, and quoted by publishers in their marketing.

Increased collegiality was a greatly appreciated side-effect of the Get Published Group. Having opportunities to collaborate and discuss writing issues with colleagues, many of whom might not interact in daily routines and who brought fresh perspectives, was a highlight for many group members. Interrelations among staff members at varying 
levels of their publishing and library careers were enriching. Increased professional involvement also included interaction with the wider institution, raising the visibility of the library.

\section{Limitations}

Although it is not possible to generalise from a small team's experience, nevertheless clear benefits were achieved and insights from this case study can be applied elsewhere. If management support is not forthcoming results may be negatively impacted. It is important to have a champion, preferably at a senior level, to 'sell' the idea of a publishing group to managers so that some time is allocated during work hours for writing. The value of librarians engaging in writing has been questioned by some (Boice et al., 1987), however in the experience of this team, any reticence on the part of supervisors was overcome as members began to publish and present. This resulted in an increased understanding of the group's value to the library and a request from the library leadership to form a new group for additional staff to gain similar benefits.

\section{Conclusion}

The RMIT University Library Get Published Group has proven to be an effective model for increasing professionals' competence, enthusiasm and success in writing, publishing and presenting. Run as a discussion and learning group, it operated democratically and all members were active in the organization of its activities. When starting a learning group, it is necessary to decide whether to follow an existing and/or comprehensive curriculum or whether to audit existing skills and tailor content to specific needs. Both approaches are valid. Building on pre-existing knowledge and experience and developing session content to meet explicit needs may promote a greater sense of ownership. The sharing of responsibility for arranging sessions in the Get Published Group developed ownership and commitment.

Investigations of writing groups and other writing interventions demonstrate that writing knowledge can be attained without this necessarily translating into action. Instead, often a simple lack of confidence holds people back from publishing (Morss and Murray, 2001). Sharing knowledge and experience and learning from experts, combined with practical application and a supportive team culture, resulted in increased confidence, competence, and publication output. Such a team benefits the individual participant through skill development, increased job satisfaction from meeting a challenge, enhanced career profile, and positive networking experiences. It also benefits the organization by raising the profile of the organization, increasing the confidence of the staff involved, and increasing staff competence in a number of areas.

Professionals attend conferences, read articles and join discussions to learn from what others are doing. In a College \& Research Libraries pre-print Sugimoto et al. (2012) found peer-reviewed journal articles and conference papers are popular sources for both professional reading and disseminating knowledge. These formal methods of communication remain relevant, and suggest that writing for publication is an effective way to make a positive contribution to the profession.

\section{References}

Blessinger, K., Braunstein, S., Daugherty, A. and Hyrcaj, P. (2010), "Formation of an academic writing group at Louisiana State University Libraries: background, guidelines and lessons learned ", Codex: The Journal of the Louisiana Chapter of the $A R C L$, Vol. 1 No. 2, pp. 18-40. 
Boice, R., Scepanski, J.M., Wilson, W. (1987), "Librarians and faculty members: coping with pressures to publish ", College and Research Libraries, Vol. 48 No. 6, pp. 494-503.

Bonebright, D.A. (2010), "40 years of storming: a historical review of Tuckman's model of small group development", Human Resource Development International, Vol. 13 No. 1, pp. 111-20.

Bradley, F. (2008), "Writing for the profession: the experience of new professionals", Library Management, Vol. 29 No. 8, pp. 729-45.

Cameron, J., Nairn, K. and Higgins, J. (2009), "Demystifying academic writing: reflections on emotions, know-how and academic identity", Journal of Geography in Higher Education, Vol. 33 No. 2, pp. 269-84.

Campbell, K., Ellis, M. and Adebonojo, L. (2011), "Developing a writing group for librarians: the benefits of successful collaboration", Library Management, Vol. 33 No. $1 / 2$, pp. 14-21.

Clapton, J. (2010), "Library and information science practitioners writing for publication: motivations, barriers and supports", Library and Information Research, Vol. 34 No. 106, pp. 7-21.

DuFrene, D.D. and Lehman, C.M. (2011), Building High Performance Teams, SouthWestern Cengage Learning, Mason, $\mathrm{OH}$.

Exner, N. and Houk, A.H. (2010), "Starting the write way: comparing two library scholarly development programs", Library Leadership and Management, Vol. 24 No. 4, pp. 178-82.

Fallon, H. (2009), "A writing support programme for Irish academic librarians", Library Review, Vol. 58 No. 6, pp. 414-22.

---- (2010), "And so it is written: supporting librarians on the path to publication", Journal of Library Innovation, Vol. 1 No. 1, pp. 35-41.

---- (2012), "Using a blended group learning approach to increase librarians' motivation and skills to publish", New Review of Academic Librarianship, Vol. 18 No. 1, pp. 7-25.

Franz, T.M. (2012), Group Dynamics and Team Interventions: Understanding and Improving Team Performance, Wiley, Chicester.

Gannon-Leary, P. and Bent, M. (2010), "Writing for publication and the role of the library: "Do have a cow, man!" ("Don't have a cow, man"-Bart Simpson)", New Review of Academic Librarianship, Vol. 16 No. 1, pp. 26-44.

Gere, A. (1987), Writing Groups: History, Theory and Implications, Southern Illinois University Press, Carbondale.

Giddens, D. (2012), "Expanding an online reference service by increasing student options", Incite, Vol. 33 No. 8, p. 11.

Gordon, R.S. (2004), The Librarian's Guide to Writing for Publication, Scarecrow, Lanham, MD.

Grant, B. and Knowles, S. (2000), "Flights of imagination: academic women be(com)ing writers", International Journal for Academic Development, Vol. 5 No. 1, pp. 6-9.

Grant, M.J., Munro, W., Mclsaac, J. and Hill, S. (2010), "Cross-disciplinary writers' group stimulates fresh approaches to scholarly communication: a reflective case study within a higher education institution in the North West of England", New Review of Academic Librarianship, Vol. 16 pp. 44-64.

Gray, T. (2005), Publish \& Flourish: Become a Prolific Scholar, Teaching Academy, New Mexico State University, [Las Cruces], New Mexico.

Haas, S. (2012), "Writing groups", in K. Draheim, F. Liebetanz and S. Volger-Lipp (Eds), Schreiben(d) Lernen im Team: Ein Seminarkonzept für Innovative Hochschullehre, VS Verlag für Sozialwissenschaften, Frankfurt, pp. 44-54. 
Hemmings, B., Rushbrook, P. and Smith, E. (2005), "To publish or not to publish: that is the question?", Journal of Learned Publishing, Vol. 18 No. 1, pp. 63-5.

Johnsrud, K. (2011), "Supporting librarian scholarship", The ALL-SIS Newsletter, Vol. 31 No. 1, pp. 3,6.

Leslie, S. (2010), "Review of Writing and Publishing: The Librarian's Handbook. Edited by Carol Smallwood", Journal of Hospital Librarianship, Vol. 10 No. 4, pp. 417-8.

Lewis, D.W. (2010), "Academic library staffing a decade from now", in S. Walter \& K. Williams (Eds), Expert Library: Staffing, Sustaining, and Advancing the Academic Library in the 21st Century, Association of College and Research Libraries, Chicago, Illinois, pp. 1-29.

Mathson, S. (2010), "Librarian writing groups", in C. Smallwood (Ed.), Writing and Publishing: The Librarian's Handbook, American Library Association, Chicago, pp. 34-5.

McGrail, M.R., Rickard, C.M. and Jones, R. (2006), "Publish or perish: a systematic review of interventions to increase academic publication rates", Higher Education Research \& Development, Vol. 25 No. 1, pp. 19-35.

Mohammed, S. and Ferzandi, L. (2007), " Team mental model", in S.G. Rogelberg (ed.), Encyclopedia of Industrial and Organizational Psychology, SAGE Publications, Thousand Oaks, CA, pp. 790-3.

Morss, K. and Murray, R. (2001), "Researching academic writing within a structured programme: insights and outcomes", Studies in Higher Education, Vol. 26 No. 1, pp. 35-52.

Palmer, P. and Matz, C. (2006), "Promoting writing among nontenured faculty: seven up, seven down ", College \& Research Libraries News, Vol. 67 No. 6, pp. 372-4.

Raish, M. (2003), "Academic librarians offer the crucial human element in online scholarship", in M.H. Raish (ed.), Musings, Meanderings, and Monsters, Too, Scarecrow Press, Lanham, Maryland, pp. 1-8.

Rankin, E. (2001), The Work of Writing: Insights and Strategies for Academics and Professionals, Jossey-Bass, San Francisco.

Sapon-White, R., King, V. and Christie, A. (2004), "Supporting a culture of scholarship for academic librarians", portal: Libraries \& the Academy, Vol. 4 No. 3, pp. 40722.

Silvia, P.J. (2007), How to Write a Lot: a Practical Guide to Productive Academic Writing, American Psychological Association, Washington, D.C.

Sugimoto, C.R., Tsou, A., Naslund, S., Hauser, A., Brandon, M., Winter, D., Behles, C. and Finlay, S.C. (2012), "Beyond gatekeepers of knowledge: scholarly communication practices of academic librarians and archivists at ARL institutions", College \& Research Libraries, available at: http://crl.acrl.org/content/early/2012/09/10/crl12-398.full.pdf (accessed 19 February 2013).

Sullivan, D. (2012a), "Guest forum: six online ways to find LIS publishing opportunities", Informed Librarian Online, January, available at: http://www.informedlibrarian.com/guestForum.cfm?FILE=gf1201.html (accessed 19 February 2013)

---- (2012b), "Publication anxiety: emotion and the stages of publishing in the library and information science literature", The Australian Library Journal, Vol. 61 No. 2, pp. 133-41.

---- (2012c), "When library DNA goes bad", Incite, Vol. 33 No. 5, p. 11.

Team Management Systems (2009), Team Management Profile, TMS, available at: http://www.tmsoz.com/team-management-profile (accessed 3 December 2012 2012). 
Tenopir, C., Mays, R., and Wu, L. (2011), “Journal article growth and reading patterns", New Review of Information Networking, Vol. 16 No. 1, pp. 4-22.

Tysick, C. and Babb, N. (2006), "Writing support for junior faculty librarians: a case study", Journal of Academic Librarianship, Vol. 32 No. 1, pp. 94-100.

University of Queensland (2012), Three Minute Thesis (3MT ${ }^{\mathrm{TM}}$ ) available at: http://www.uq.edu.au/grad-school/three-minute-thesis (accessed 19 February 2013).

West, M.A. (2004), Effective Teamwork: Practical Lessons from Organizational Research, 2nd edn, BPS Blackwell, Malden, MA. 
Blessinger, K., Braunstein, S., Daugherty, A. and Hyrcaj, P. (2010), "Formation of an academic writing group at Louisiana State University Libraries: background, guidelines and lessons learned", Codex: The Journal of the Louisiana Chapter of the ARCL, Vol. 1 No. 2, pp. 18-40.

Campbell, K., Ellis, M. and Adebonojo, L. (2011), "Developing a writing group for librarians: the benefits of successful collaboration", Library Management, Vol. 33 No. 1/2, pp. 14-21.

4 tenure track

librarians. USA.

Critique

Review

Experts review submitted papers

3 authors but

group numbers

not specified.

USA.
Critique

Collaborative writing
Advantages:

- Increased confidence
Exner, N. and Houk, A.H. (2010), "Starting the write way: comparing two library scholarly development programs", Library Leadership and Management, Vol. 24 No. 4, pp. 178-82.
Group numbers not specified. Half of the tenure track librarians are at both institutions. USA.

Country wide program involving lecturing and library staff since 2007. Ireland.

\section{Two groups:}

1. The Pub \& Grub ModelInformal, unstructured, goa setting, some writing done after discussion.

2. Agraphia group/Guided by books Paul Silvia's How to Write a Lot. Goal setting accountability group.

Blended approach - online tasks, faceto-face peer reviews and workshops. On-line mentoring group. approach to increase librarians motivation and Librarianship, Vol. 18 No. 1, pp. 7-25.
Critique and review by author of this article via emails.
Advantages:

- Increased productivity

Disadvantages:

- Exclusion

Outcome:

- Four articles

- Nine presentations

\section{Advantages:}

- Increased confidence

Disadvantages:

- Considerable amount of time needed to run group successfully

\section{Advantages:}

- Increased confidence

- Increased productivity

- Collegiality and support network

- Own time and space 
Grant, M.J., Munro, W., Mclsaac, J. and Hill, S. (2010), "Cross-disciplinary writers' group stimulates fresh approaches to scholarly communication: a reflective case study within a higher education institution in the North West of England", New Review of Academic Librarianship, Vol. 16 pp. 4464.

Mathson, S. (2010), "Librarian writing groups", in C. Smallwood (ed.), Writing and Publishing: The Librarian's Handbook, American Library Association, Chicago, pp. 34-5.

Sapon-White, R., King, V. and Christie, A. (2004), "Supporting a culture of scholarship for academic librarians", portal: Libraries \& the Academy, Vol. 4 No. 3, pp. 407-22.

Tysick, C. and Babb, N. (2006), "Writing support for junior faculty librarians: a case study", Journal of Academic Librarianship, Vol. 32 No. 1, pp. 94100.
1 librarian, 22 University staff members and post graduate students.

$$
\text { UK. }
$$

6 academic librarians. USA.

Tenure and untenure library faculty.

6 junior faculty librarians. USA.
Learning and accountability group.

Cross-disciplinary and learning writing group.

rearning and accountability group.

Research writing group.

Part of a research writing support group program.

Critique, discussion and review group.

Guided by book: Elizabeth Rankin's

The Work of Writing.

The group was psychosocial,

mentoring and peer-led.
Advantages:

- Increased confidence

- Increased productivity Used questionnaire survey before forming group.

\section{Advantages:}

- Increased confidence

- Increased productivity

Advantage:

- Peer support

Disadvantage:

- Low submission of manuscripts for critique

Goal achieved:

"Support every librarian in the group in the effort to publish one peer-reviewed article or book."

Table I Library writing groups 


\begin{tabular}{lccc}
\hline \multicolumn{1}{c}{ Topic } & $\begin{array}{c}\text { Average rating } \\
\text { (10 point scale) } \\
\text { May 2011 }\end{array}$ & $\begin{array}{c}\text { Average rating } \\
\text { (10 point scale) } \\
\text { October } 2012\end{array}$ & $\begin{array}{c}\text { \% increase in } \\
\text { confidence }\end{array}$ \\
\hline Peer review process & 5.13 & 8.57 & $67.06 \%$ \\
$\begin{array}{l}\text { Copyright for authors } \\
\text { Book reviewing }\end{array}$ & 4.63 & 7.43 & $60.48 \%$ \\
$\begin{array}{l}\text { Use of research methodologies, e.g. } \\
\text { survey techniques, case study, } \\
\text { phenomenology }\end{array}$ & 5.75 & 8.14 & $31.57 \%$ \\
$\begin{array}{l}\text { Selecting a relevant } \\
\text { conference/seminar to present at }\end{array}$ & 4.63 & 6.43 & $38.88 \%$ \\
$\begin{array}{l}\text { Finding/selecting a journal, book etc. } \\
\text { to submit a publication to }\end{array}$ & 6.38 & 8.63 & $32.13 \%$ \\
$\begin{array}{l}\text { Presentation technologies, e.g. } \\
\text { PowerPoint, Prezi }\end{array}$ & 6.13 & 8.43 & $30.51 \%$ \\
\hline
\end{tabular}

Table II Confidence Survey: Topics surveyed in March 2011 and October 2012 with greater than $30 \%$ increase in confidence.

Getting published: Group support for academic librarians (Sullivan, Leong, Yee, Giddens, Phillips, 2013) 